hill in 1876 , and by himself in 1877 . Sir W. Herschel's measures may be set aside at once as not sufficiently exact for a discussion of a moderate proper motion; his angle in $I 78 \mathrm{I}$ is the result of a single measure, and his distances, as is well known, are in defect, when they exceed a minute. Taking then Struve's epoch, $183^{\circ} 06$, as the earliest reliable datum we possess, and bringing it up to Dembowski's epoch, I863.37, with Leverrier's proper motion for Aldebaran, we find no greater difference than may be accounted for by unavoidable error of observation, so that Struve's inference on comparing the Pulkowa measures, in 1851 with the Dorpat measures of 1836 , "itaque comes motus non est particeps, sed in cœlo quiesca videtur," and Dembowski's conclusion when speaking of this objecr and of $\lambda$ Aurigre," "Les différenres s'accordent assez bien avec les mouvements propres des deux principales," are thus supported. The angle, however, should now be less than is assigned by Mr. Gledhill and M. Flammarion from their own measures $\left(35^{\circ} \cdot 5\right)$, and further careful measures will be desirable to clear up a possible question of personal equation. If we reduce Struve's angle for 1836 with Leverrier's proper motion of Aldebaran to the present year, we find an angle nearer $32^{\circ} \cdot 5$ than $35^{\circ} 5$.

THE THIRD CONET OF 1759.-This comet was not observed until January, 1760 , but appears in our catalogues as comet 1759 III., from the circumstance of the perihelion passage having occurred in December of that year. It approached very near the earth, but was not a conspicuous object more than a few days. There are several references to the comet in the Ammual Register for 1760 , where we learn that it was "discovered and astronomically observed by Mr. Dunn at his Academy at Chelsea," who had determined the positions of Halley's comet on every evening during the first week of May previous. Pingré states that the sky, having been constantly overcast at Paris for several days, all the astronomers of that capital, including Cassini de Thury, Maraldi, Lacaille, and Messier, detected the comet on the evening of January 8 ; Dunn is credited with having found it on January I. It was seen at Lisbon on January 7. For the purpose of these remarks we shall adopt the elements of Lacaille, in deducing the apparent places of the comet.

There is no reason why the coniet should not have been found on January $\mathbf{r}$, if atmospherical conditions had been favourable, but it must have been on the morning, not on the evening of that day. In fact, the comet would rise soon after I o'clock A.M., in London, and would be upon the meridian a few minutes before six at an altitude of more than $23^{\circ}$. It is, however, distinctly stated in the Annual Register that Dunn discovered the comet in the evening, that "it appeared to the naked eye like Jupiter or Venus through a thick fog, and made a near appulse to the star in Orion's right knee, and moved more than four degrees of the heavens in four hours of time." This can only refer to the evening of January 8 . The elements give the following positions:-

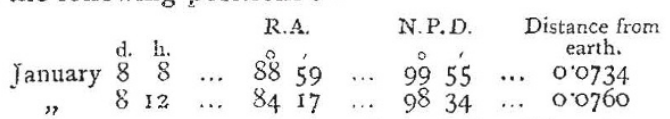

There was, therefore a motion of upwards of four degrees in as many hours, and soon after midnight the comet would not be more than $I_{\frac{1}{4}}^{\circ}$ from Orion's right knee, or $\kappa$ Orionis. It is therefore pretty certain that Dunn did not precede other observers by a week, as might at firs sight appear from the statement in the Register. Clouded skies had evidently prevailed in Western Europe for some days, and the comet was detected on the same evening, January 8, on the heavens clearing, in England, France, and Holland.

The rapid course of this retrograde comet will be apparent from the following positions, calculated for Greenwich midnight.

\begin{tabular}{|c|c|c|c|c|c|c|}
\hline & & R.A. & & N.P.D. & & Distance. \\
\hline Jan. 5 & $\ldots$ & r6̊ $5 \dot{6} 6$ & $\ldots$ & 1ำ 2́2 & $\ldots$ & $0.1 \times 2$ \\
\hline$" 6$ & $\ldots$ & 14711 & $\ldots$ & II0 3 & $\ldots$ & $0.08_{3}$ \\
\hline 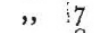 & $\ldots$ & 11627 & $\ldots$ & 10658 & $\ldots$ & 0.068 \\
\hline$\Rightarrow 8$ & $\ldots$ & 8417 & $\ldots$ & 9834 & $\ldots$ & 0076 \\
\hline " 9 & $\ldots$ & 649 & $\ldots$ & 9130 & $\ldots$ & $0 . \mathrm{YOI}$ \\
\hline$\Rightarrow 13$ & $\ldots$ & 3922 & $\ldots$ & 8233 & $\ldots$ & 043 \\
\hline
\end{tabular}

Between January 7 and 8 the comet passed over $32 \frac{1}{2}^{\circ}$ in arc of great circle, and was nearest to the earth soou after midnight on the former date. On January 9 in the evening Dunn says the comet passed near $\mu$ and $\nu$ in Eridanus, and we find from Lacaille's elements that at 5 h. $39 \mathrm{~m}$. P.M. it would have the same right ascension as $\mu$, with only $40^{\prime}$ greater declination. So far as reg position the comet might have been observed as eariy as the day of perihelion passage, December 16 , when it was in R.A. $199^{\circ}$ and N.P.D. $103^{\circ}$, rising ir Lendon at 2h. $45 \mathrm{~m}$. A.M. ; but the intensity of light was only $\frac{1}{12} \pi^{\text {th }}$ of that on the evening of January 8 , when it was generally discovered. It is rather unfortunate that it was not observed over a longer period, since it appears certain that in its approach to perihelion it must have passed very near to the planet Jupiter, and we night expect a sensible deviation from the parabola. On November 7 , i758, Lacaille's orbit would give the comet's distance from Jupiter less than $0^{\circ} \circ$ g. $^{\circ}$

\section{METEOROLOGICAL NOTES}

SUN-SPOTS AND RAINFALL OF CaLCUTTA,-.-Mi. E Douglas Archibald, of Naini Tal, has written au interesting letter to The Englishman, the leading Calcutia newspaper, in which he shows from the observations made from 1837 to 1876 , that the winter rainfal (Nov. to April inclusive) of Calcutta is marked by a disinct periodicity, the maximum rainfall occuring duting the years of minimum sunspots, and the minirnum rainfal] during the years of maximum sun-spots. The following are the figures for the years of the sun.spot cycie beginning with the year of minimum sur-spots :-

\begin{tabular}{|c|c|c|c|c|}
\hline \multicolumn{2}{|c|}{ Ist and 2nd year of cycle } & \multicolumn{3}{|c|}{$\begin{array}{c}\text { Average Rainfall } \\
6.44 \text { inches }\end{array}$} \\
\hline 3 rd and 4 th & " & $\ldots$ & 5.93 & \\
\hline and 6 th & $"$ & $\ldots$ & $4 \cdot 44$ & \\
\hline nd 8 th & $\because$ & $\ldots$ & 5.03 & $"$ \\
\hline$\pi$ & $"$ & $\ldots$ & 6.15 & " \\
\hline & $"$ & $\ldots$ & 8.49 & \\
\hline
\end{tabular}

the average rainfall for the forty years being 54 inches. Mr. Archibald is of opinion that this peculiarity, which is the reverse of what obtains as regards the rainfall of the whole year, in its relation to sunspots, will be found not to occur much farther south than Celcutia, and that it will be more decidedly marked over the region farther to the north lying more immediately und the great range of the Himalayas. The point is one of very considerable interest and deserves the fullest investigation, since, if the supposition proves to be correct, it will doubtless lead to a more exact method of examining the rainfall in its relation to sun-spots. It may bo remarked that the winter rainfall at Sydney (in the southern hemisphere) from 1840 to 1876 , which is situated within the latitudes indicated by Mr. Archibald, exbibits the same peculiarity as that of Calcutta in its relation to the sun-spot period.

Winds of the South Atlantic.-M. Brault announces the publication by the French Marine of a series of new meteorological charts giving the direction and force of the winds of the South Atlantic for each of the fout seasons, the charts being similar to those published by M. Brault about two years ago on the winds of the North Atlantic. The new charts contain the results of 189,573 observations of the wind. The general movement of the winds in summer over this portion of the globe resembles 
an immensc whirl whose centre is about $30^{\circ}-35^{\circ}$ lat. S., and $10^{\circ}-20^{\circ}$ long. W. The whirling movement is in a direction contrary to that of the hands of a watch, being thus opposite to the general circulation of the atmosphere over the North Atlantic in summer. Out from this centre winds blow in all directions, the more important being the south-east trades, which are deflected to south and south-south-west off the coast of Africa, and to east-south-east and east on approaching America; then in succession north-east, north, and north-west winds on advancing southward along the coast of Amcrica, merging finally in the westerly winds which blow across the Atlantic from Cape Horn to the Cape of Good Hope. Looking both at the direction and force of the winds, $M$. Brault concludes that the results establish beyond a doubt the fact that, contrary to views entertained up to a comparatively recent date, there does not exist any tropical zone stretching across the South Atlantic, characterised by the prevalence of calms and light variable breezes. These results are in entire accordance with recent researches into the atmospheric movements over this region, and are of peculiar interest when viewed in connection with the distribution of atmospheric pressure and its variation with season over South America, the South Atlantic, and South Africa.

Climate of Kosseir, ON THE. Red SEA.--In the last number of the fournal of the Austrian Meteorological Society, p. 225, there is an interesting article on the climate of Kosseir, on the Red Sea, based on a year's observations by Dr. Klunzinger during $1872-73$. The interest of the climate of this region lies in its extreme character in certain directions, and the regularity of occurrence of its changes from season to season. The mean atmospheric pressure is $30^{\circ} 020$ inches, rising to the maximum 30.213 inches in January, and falling to the minimum 29.863 inches in July, showing thus a vari.. ation of 0.350 inches in the monthly means. The mean temperature is $76^{\circ} \cdot 3$, the warmest month, August, being $84^{\circ} 9$, and the coldest, January, $64^{\circ} \cdot 9$. There is little cloud in any season, and in summer the skies are constantly all but cloudless. A prominent feature of the climate is its dryness, the mean relative humidity for the year being only 56 , falling in June to $5 \mathrm{I}$, and rising to 62 in November. This great dryness is due to the winds, which are northerly and north-westerly during the whole year, the only change being from about northnorth-west in summer to north-west in winter. Occasionally, however, when easterly winds set in, the air becomes so saturated that everything is wetted with the vapour with which it is heavily charced. On June 4, 1873, a "Samum" commenced (north-north-west, force 7), the horizon having a grey troubled appearance, the sky cloudless, and the air hot and dry; it continued till the 6 th, and it was during this strong dry wind that the highest temperature, $93^{\circ} 9$, was observed.

DROUGHT IN CANADA.-An unusual drought has prevailed in Canada during the past spring. Little rain having fallen for ten weeks, the waters of the Ottawa and St. Maurice, two of the principal lumbering rivers, bave been reduced to their summer level, having never before been so low at this season. A serious consequence of this state of matters is, that very large quantities of the finest timber of the dominion nust remain in the woods till next year.

\section{EARLY ALLUSIONS TO THE MAGNETIC NEEDLE}

$\Lambda T$ recent meetings of the Literary and Philosophical Society of Manchester interesting contributions to the subject were made. In a paper by $\mathrm{Mr}$. H. Grimshaw he refers to such an allusion in a work entitled, "An Apologie of the Power and Providence of God in the
Government of the World; or, An Examination and Censure of the Common Error touching Nature's Perpetual and Universal Decay: Divided into Four Books." The author is one "G. H.," D.D. (Doctor of Divinity), and the work is printed at Oxford by John Litchfield and William Turner, "Printers to the famous University," Anno Domini 1627 , being therefore exactly 250 years old.

The third book of the four into which the work is divided treats of "The pretended decay of mankind in regard and duration, of strength and stature, of arts and wits." The tenth chapter of this third book is said to be "Touching diverse artificiall workes and usefull inventions, at leastwise matchable with those of the ancients, namely and chiefly the invention of Printing, Gunnes, and the Sea-Gard or Mariners Compasse." This tenth cbapter again, for such is the orderly division of the subjects, is subdivided into four sections, and the fourth of these is headed "Of the use and invention of the Mariners Compasse or sea-card, as also of another excellent invention sayd to be lately found out upon the Load-stone, together with the conclusion of this comparison touching Arts and Wits, with a saying of Bodius, and another very notable one of Lactantius."

It is in the account of this "excellent invention sayd to be lately found out upon the loadstone" that a curious prevision or dream, so to speak, of the application of electricity as a means of communication occurs, and there is small wonder that the old philosopher called it as he does further on, "an excellent and secret conclusion upon the stone," for, whilst perusing his description, one can hardly imagine that the writer has not in his mind's eye one of our most modern telegraphic instruments. The paragraph is as follows :-

"Another excellent and secret conclusion upon this stone, pretended to be found out in these latter times, is, that by touching two needles with the same stone, they being severally set so as they may turne upon two round tables, having on their borders, the Alphabet within circlewise, if two friends agreeing upon the time, the one in Paris, the other in London (having each of them their table thus equally fitted) be disposed upon certayne dayes and at certaine houres to conferre, it is to bee done by turning the needle in one of the tables to the Alphabet, and the other, by Sympathie will turn itself in the same manner in the other table though never so farre distant : which conclusion if infallibly true, may likewise proove of good and great consequence; howsoever, I will set it down as I find it described by Famianus Strada in imitation of the stile and vaine of Lucretizs."

\section{Magnesi genus est lapidis mirubile, \&c., \&c.}

Then follows the extract in Latin, with the English translation in verse attached.

It will be acknowledged by any one familiar with the instrument, that the dial telegraph of Cooke and Wheatstone, invented subsequently to their first upright needle form, most curiously carries out the ideal description of this old author, and it will be seen that the date at which his work is written was nearly 200 years prior to the first attempt made to communicate at a distance by means of magnetic needles.

Prof. Stanley Jevons, in a subsequent paper, stated that ten years ago he spent some trouble in investigating this curious anticipation of the telegraph, but only published the results in the form of a brief anonymous article in a weekly newspaper. This curious subject, Mr. Jevons thinks, has not received the attention which it seems to deserve, but it was not wholly unknown. The Abbé Moigno, in his "Traité de Télégraphie Electrique" (Paris, 1852 ), alludes to what he calls this "Charmant rêve, ou operation necromancienne," and he points out that Addison had quoted the remarkable verses of Famianus Strada in the Spectator, No. 24I. Addison speaks of "a chimerical correspondence between two 